As regards the production of iron ore, the total amount raised in 1913 was just under 16 million tons, to which Cleveland contributed nearly 6, Northamptonshire 3 , Lincolnshire $2 \cdot 6$, and Cumberland $\mathrm{I} \cdot 3$ million tons. The above total compares unfavourably with the output in 1880 , which was above 18 million tons. Scotland, which then contributed 2.66 million tons, only produced 0.59 million tons in 1913. Staffordshire also shows a big decline. On the other hand, imported ores had risen from 3 million tons in 1880 to 8 million in 1913 , of which 47 came from Spain. Thus some 24 million tons of iron ore were raised and smelted in 1913 , of which slightly above onethird came from abroad. A total of 10.26 million tons of pig iron was produced, representing an average iron content of $42 \cdot 7$ per cent. in the ore.

The resources of the British Dominions are then referred to, the principal deposits at present known being those of Newfoundland, Canada, India, and Australia. Two of the largest iron mines in the world are situated on the northwestern shore of Bell Island, Newfoundland, and from them the Canadian iron industry has drawn its chief ore supplies. Immense resources of iron ore are known to exist in India, but no definite estimate of the quantities available for exploitation has ever been made.

Part ii. gives information of the same kind and so far as it is available with regard to most of the other countries of Europe, Africa, Asia, and North and South America. As regards the ironore deposits of the United States, the economic and industrial conditions render it unlikely that those ores will ever be imported into this country. So far as the iron industry of the United Kingdom is dependent on the iron resources of other countries, any supplies drawn from the United States will probably always be in the form of pig iron or semi-finished and finished iron goods.

In Part iii. notes are given of the principal uses, occurrence, and composition of the ores of metals other than iron but used in the iron industry-viz. chromium, cobalt, manganese, molybdenum, nickel, titanium, tungsten, vanadium, and zirconium, including references to the composition of ferro-alloys manufactured from some of these ores.

\section{THE EFFORTS OF FRENCH INDUSTRY} DURING THE WAR.

WHILE the various Allied countries are busily occupied in discussing elaborate after-war programmes, there is evidence that France at least has passed the domain of mere theoretical speculation. The Société d'Encouragement pour l'Industrie Nationale recently organised at its headquarters in Paris an exhibition of national industries, the exhibits comprising : (a) products manufactured in France since the outbreak of the war, and which prior to the war were all-or nearly all-obtained from abroad; $(b)$ products which before the war were manufactured principally in the regions now in enemy occupation and are now manufactured beyond the French Army zone. A description of the exhibits is given in the JulyAugust number of the society's Bulletin, and the following brief notes refer to the products of a more or less scientific character.

Quartz and Glass Goods.-MM. Adnet and Poulenc Frères exhibited a comprehensive series of glass and quartz vessels used in chemical and bacteriological work, including some specimens of "tuboserum" glass which M. Adnet has manufactured to replace the neutral Jena glass. Other exhibits included Dewar bottles, nitrometers, gas determination apparatus, clinical thermometers, and a microscope the optical and mechanical parts of which were made entirely in France. Special interest attached to the exhibit of a Coolidge tube, which has now assumed importance in connection with the radiography of metals.

Chemistry.-At the outbreak of war France was practically entirely dependent on Germany or on German-owned companies for her supplies of chemicals necessary for the manufacture of high explosives. The war has changed all that, as is evident from the long list of organic compounds shown at the exhibition now under discussion. A comprehensive series of samples of the coaltar derivatives was shown, as well as samples of synthetic nitric acid and nitrates obtained from French works. Again, the French have taken up in earnest the manufacture of pharmaceutical products which were essentially German specialities before the war (aspirin, local anæsthetics, hypnotics, etc.), as the list of exhibits shows. Many compounds used in the manufacture of dyes, varnishes, etc., and in connection with photography and radiology were shown. Progress has also been made in the manufacture of compounds of the rare earths, which in peace time were obtained exclusively from Germany, while pure cerium, ferro-cerium, and magnesium (manufactured for the first time in France) have now passed the experimental stage. Three novelties in the way of chemicals were represented in synthetic acetic acid, synthetic acetic anhydride, and synthetic alcohol.

Miscellaneous.-Ebonite, so largely used in scientific instruments of all kinds-especially electrical - had to be obtained from German firms by France at the outbreak of war. Many samples of ebonite goods were included in the present exhibition, and it is hoped that France may after the war be self-supporting in this respect. The French are also taking up actively (as we are in this country) the manufacture of magnetos, and it is hoped, with the advent of better labour conditions, to replace foreign-made goods by the French article.

It would be highly interesting and instructive from the economic point of view if British manufacturers of articles similar to those described organised a comprehensive exhibit on the lines indicated above. The country would then at least know that serious attempts were being made to take action rather than spend time in abstruse arguments which have little value except for the theoretical economist.

E. S. Hodgson. NO. 2500 , VOL. IOO] 